\title{
UFC-CRAb: A group on Computer graphics, virtual Reality and Animation
}

\author{
Creto Augusto Vidal and Joaquim Bento Cavalcante-Neto \\ Department of Computing (DC) \\ Federal University of Ceará (UFC) \\ Fortaleza-CE, Brazil \\ \{cvidal, joaquimb\}@lia.ufc.br
}

\begin{abstract}
This paper describes the history, mission, objectives, research lines and ongoing projects of UFC-CRAb, a research group on computer graphics, virtual reality and animation at the Federal University of Ceará (UFC).
\end{abstract}

Keywords: computer graphics; virtual reality; animation

\section{INTRODUCTION}

UFC-CRAb (http://crab.dc.ufc.br/joomla) is a research group on Computer graphics, virtual Reality and Animation, associated with the Masters and Doctorate Program in Computer Science (MDCC) of the Department of Computing (DC) at the Federal University of Ceará (UFC), Brazil (www.mdcc.ufc.br, www.dc.ufc.br, www.ufc.br).

UFC-CRAb is an interdepartmental research group, active in the areas of Computer graphics, Virtual reality and Animation, and involving researchers from two departments (Computing and Mathematics). The group was created in the year 2000, and incorporated the former Computer Graphics Laboratory of the department of Computing. Its mission is to contribute to the advancement of the areas of Computer Graphics, Virtual Reality and Animation, and to the formation of skilled researchers in the field. It also aims at applying computer graphics technology to solving problems demanded by society.

The group develops relevant projects in many areas related to Computer graphics (Meshing and Rendering), Virtual reality (Virtual Environments and Artificial Life) and Animation (Direct Dynamics and Controller Simulation). As examples of research topics in these areas, recently the group has been working on: adaptive meshing for applications in virtual reality and engineering; biologically-inspired generation of virtual characters and applications; realistic rendering methods and applications; collaborative virtual environments; sculpting; animation of virtual characters and clothing; development of efficient and adaptable graphics engines; and behavior of autonomous virtual characters.

UFC-CRAb offers an excellent infrastructure for graduate research at Masters and $\mathrm{Ph} . \mathrm{D}$. levels, and a friendly atmosphere that fosters teamwork and leadership. Since the beginning of the masters program in 1995 and the doctorate in 2005, the group has formed 23 masters, and, in 2011, it will form the first two doctors. Today, the group houses nine master students and eleven doctorate students, and take part in several interinstitutional cooperation and research projects. UFC-CRAb has maintained cooperation with Tecgraf of PUC-Rio in many areas related to Computer graphics, with the Cornell Fracture Group of Cornell University in the areas related to Meshing, and with the Animation Group of the University of California at Riverside in the areas related to Dynamic Simulation.

\section{RESEARCH TOPICS}

In this section, we present the ongoing research topics listed in Section I. All the topics are either embedded in a larger project, or receive direct financial support from the Brazilian funding agencies CAPES, CNPq and FUNCAP.

\section{A. Adaptive mesh generation for applications in virtual reality and engineering}

This research aims at developing adaptive meshing algorithms for arbitrary 2D and 3D domains, as well as for parametric surfaces [23, 24] (Figure 1).

We have developed efficient algorithms for sequential and parallel processing of 2D domains with and without cracks, based on the Advancing Front Technique [6]. We also developed an optimized pattern-based adaptive mesh refinement technique using GPU [11]. A mesh generation technique controlled by curvature was developed for $3 \mathrm{D}$ parametric surfaces [23].

Currently, we are extending the sequential and parallel techniques: to generate meshes of convex quadrilateral elements for arbitrary 2D domains and surfaces; to generate meshes of tetrahedral and hexahedral elements for arbitrary 3D domains; to generate surface meshes for non-manifold problems.

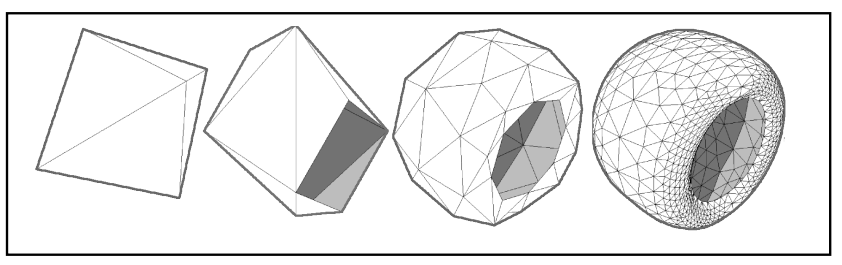

Figure 1. Mesh generation of a parametric model of a tire. 
B. Biologically-inspired generation of virtual characters and applications

This research line uses the biological concept of diploidy, and simulates the gamete generation process of meiosis. After fecundation, a simulated chromosomal data structure is used to construct the virtual characters [30]. That idea has been applied to generate diversity [32], and to transmit traits from ancestors to descendants $[31,34]$. That technique is useful in applications such as games, virtual reality, and crowd simulation [33, 35, $36,37]$. Recently, it is being applied in a research for solving the missing persons problem [3] (Figure 2).

The next steps in our research are: the extension to fullbody representation; the inclusion of growth model to represent body and facial changes from childhood to adulthood; and inclusion of an aging model.

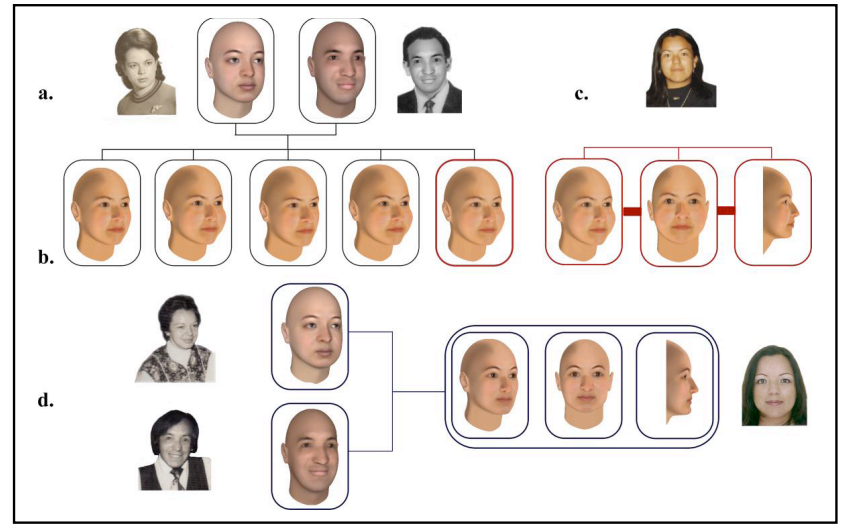

Figure 2. Missing person problem.

\section{Collaborative virtual environments}

The focus of this research is on mapping requirements specified in the area of CSCW (Computer Supported Cooperative Work) to networked virtual environments. We have developed networked virtual environments for education and training [1, 2, 10, 22, 25-29].

Currently, we are interested in making collaborative virtual environment a practical and effective tool in education and training. In this area, the challenges are immense, and there is much room for collaboration with other groups.

\section{Sculpting}

This is a very recent initiative of the group. The focus is on developing intuitive manipulation tools for sculpting and clever data structures and topological operations to support local model adaptations.

We are working on an adaptive refinement technique for virtually sculpting small details in triangular meshes; and on multiresolution sculpting techniques.

\section{E. Development of efficient and adaptable graphics engines}

This research is focused on developing graphics engines for game applications [12-14].
Currently, we are evolving our CRAbGE graphical engine to make it useful in developing multiplatform games.

\section{F. Behavior of autonomous virtual characters}

The goal of this research is the representation of natural and realistic behaviors of autonomous virtual characters through the use of Enactive Artificial Intelligence [15-16].

At the moment, we are working on a model that will make the emergence of behavior possible. We are looking at ways of making virtual characters sense the stimuli of the virtual environment and develop coherent behavior.

\section{G. Realistic rendering methods and applications}

The focus of this research is on rendering point clouds and splats, and on methods of global illumination with special treatment of the equation of light transport [7-9] (Figure 3).

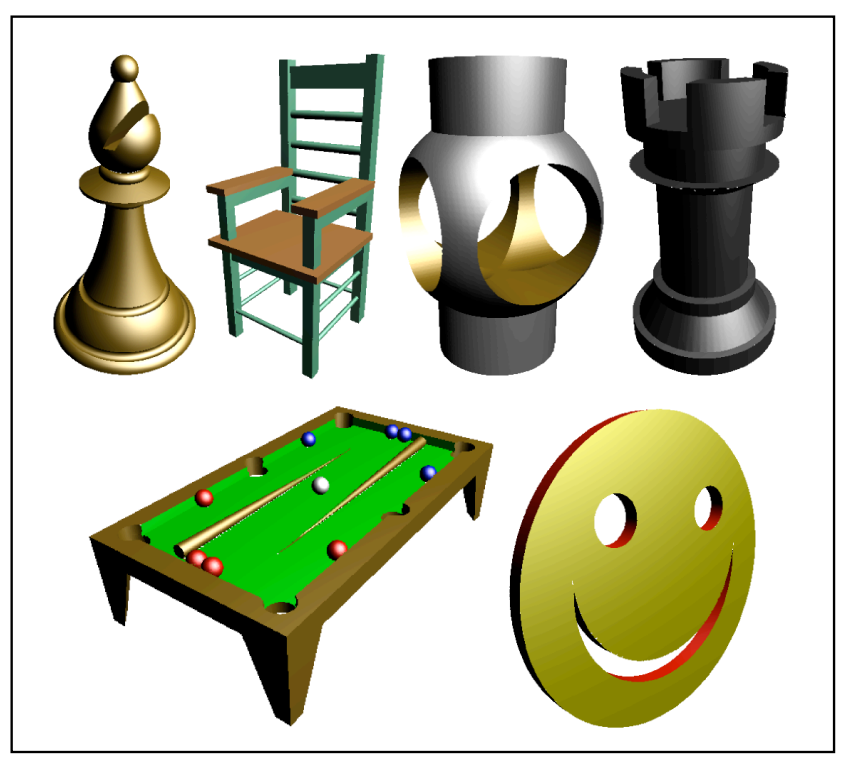

Figure 3. Rendering of splat-based models.

We are interested in rendering realistically: low density splat-based models, and natural phenomena.

\section{H. Crowd simulation}

This research focuses on the comprehension of crowd behavior and on developing algorithms to simulate crowd movements under different situations [5] (Figure 4). Recently we are investigating evacuation of crowded spaces in emergency situations.

In our current work, we are testing a hybrid method for simulating crowds with varied behaviors in real time. The proposed model use multiple grids (potential fields), with different levels of discretization, to reduce the cost of computing potential fields, with cells of varied sizes according to environmental needs or modeled behavior. 


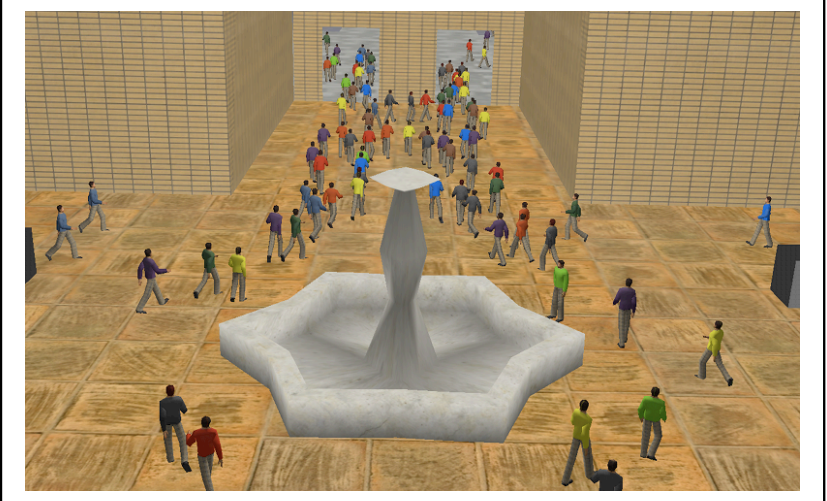

Figure 4. Crowd simulation.

\section{Animation of virtual characters and clothing}

In animation of virtual characters, we exploit the natural vibration modes of a physically based character in order to provide a palette of animation basis modes that animators can use to assemble desired motions (Figure 5) [4, 17-21].

In clothing animation, we concentrate on realistic modeling and simulation, using mass-damp-spring systems. Efforts for using the finite element method are under way.

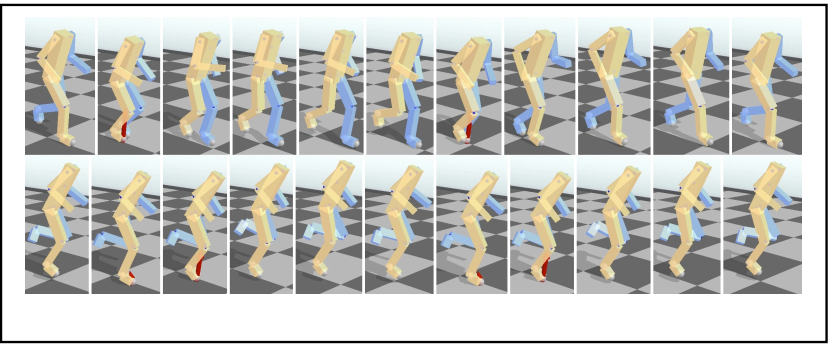

Figure 5. Animation of virtual characters using controllers.

\section{COLLABORATION}

Currently our group maintains collaboration with other groups in Brazil and abroad in the areas of mesh generation and animation. We are open to collaboration in all the research topics described in Section II. We also seek highly motivated students with strong interest in computer graphics, virtual reality or animation. Strong background in mathematics and computer graphics is desirable.

\section{ACKNOWLEDGMENT}

The authors acknowledge CAPES, CNPq and FUNCAP for the financial support of most of the projects described herein.

\section{REFERENCES}

[1] Almendra, Camilo Camilo; VIDAL, C. A.; Leite Junior, Antônio José Melo; Santos, Emanuele Marques dos; Campêlo, Luiz David Sales de Paula. A Web System for Managing and Accessing NVEs Using CORBA. In: VI Symposium on Virtual Reality, 2003, Ribeirão Preto. Proceedings of th 6th Symposium on Virtual Reality. Ribeirão Preto: Faculdades COC, 2003. v. 1. p. 297-308.
[2] Campêlo, Luiz David Sales de Paula; Castro, Miguel Franklin; Vidal, Creto; Bonfim, Michel Sales; Pequeno, Mauro Cavalcante. Um Modelo para Gerenciamento Remoto de Falhas em Ambientes Virtuais Colaborativos. In: 8th International Information and Telecommunication Technologies Symposium, 2009, Florianópolis. Proceedings. São Paulo: Pearson, 2009. v. 1. p. 1-7.

[3] Cárdenas, Martha Isabel; Vieira, Roberto César Cavalcante; Vidal, Creto; Cavalcante Neto, Joaquim Bento. Towards the Solution of the Missing Persons Problem by Simulated Reproduction of Virtual Characters. In: 23rd SIBGRAPI Conference on Graphics, Patterns and Images, 2010, Gramado. Proceedings of the 23rd Conference on Graphics, Patterns and Images. Los Alamitos: IEEE Computer Society, 2010. v. 1. p. 301-308.

[4] Carvalho, Schubert; Boulic, Ronan; Vidal, Creto; Thalmann, Daniel. Propagating Latent Edited Poses across Eigen-motions. In: Computer Graphics International, 2011, Ottawa. CGI 2011 - Computer Graphics International 2011. Ottawa: To be defined, 2011. v. 1. p. 9 pages.

[5] Dutra, Teófilo Bezerra; Cavalcante Neto, Joaquim Bento; Vidal, Creto. Um Modelo Híbrido para Simulação de Multidão com Comportamentos Variados em Tempo Real. In: Symposium on Virtual and Augmented Reality, 2011, Uberlândia. Proceedings of the XIII Symposium on Virtual and Augmented Reality. Los Alamitos: IEEE Computer Society. v. 1.p. 9 pages.

[6] Freitas, Markos Oliveira; Cavalcante Neto, Joaquim Bento; VIDAL, C. A. Geração em Paralelo de Malhas Bidimensionais com Fraturas por Avanço de Fronteira Baseada em Decomposição espacial. In: XXIX CILAMCE - Congresso Ibero Latino Americano de Métodos Computacionais em Engenharia, 2008, Maceió. XXIX CILAMCE Congresso Ibero Latino Americano de Métodos Computacionais em Engenharia. Rio de Janeiro: ABMEC, 2008. v. 1. p. 1-14.

[7] Ivo, Rafael Fernandes; Vidal, Creto; Cavalcante Neto, Joaquim Bento. Novo Método de Reconstrução de Superfícies de Modelos Baseados em Splats. In: Symposium on Virtual and Augmented Reality, 2011, Uberlândia. Proceedings of the XIII Symposium on Virtual and Augmented Reality. Los Alamitos: IEEE Computer Society, 2011. v. 1. p. 8 pages.

[8] Ivo, Rafael Fernandes; Vidal, Creto; Cavalcante Neto, Joaquim Bento. Recorte de Splats Adaptado às Curvaturas das Arestas. In: Symposium on Virtual and Augmented Reality, 2011, Uberlândia. Proceedings of the XIII Symposium on Virtual and Augmented Reality. Los Alamitos: IEEE Computer Society, 2011. v. 1.p. 8 pages.

[9] Ivo, Rafael Fernandes; Vidal, Creto; Cavalcante Neto, Joaquim Bento. A new method for cutting splats of models with sharp features. In: XXIV Sibgrapi Conference on Graphics, Patterns and Images, 2011, Maceió. Proceedings of the XXIV Sibgrapi Conference on Graphics, Patterns and Images. Los Alamitos: IEEE Computer Society, 2011. v. 1. p. 8 pages.

[10] Leite Junior, Antônio José Melo; VIDAL, C. A.; Almendra, Camilo Camilo; Santos, Emanuele Marques dos; Gomes, Humberto Ovídio Osório; Mendonça Junior, Glaudiney Moreira. Um ambiente virtual compartilhado voltado para entretenimento. In: V Symposium on Virtual Reality, 2002, Fortaleza. Proceedings of the 5th Symposium on Virtual Reality. Fortaleza: Banco do Nordeste, 2002. v. 1. p. 138-149.

[11] Lenz, Ricardo; Cavalcante Neto, Joaquim Bento; Vidal, Creto. Optimized Pattern-Based Adaptive Mesh Refinement Using GPU. In: Brazilian Symposium on Computer Graphics and Image Processing (Sibgrapi 2009), 2009, Rio de Janeiro. XXIInd Brazilian Symposium on Computer Graphics and Image Processing. Los Alamitos: IEEE Computer Society, 2009. v. 1. p. 88-95.

[12] Maia, José Gilvan Rodrigues; Cavalcante Neto, Joaquim Bento; VIDAL, C. A. CRAbGE: Um Motor Gráfico Customizável, Expansível e Portável Para Aplicações de Realidade Virtual. In: VI Symposium on Virtual Reality, 2003, Ribeirão Preto. Proceedings of the 6th Symposium on Virtual Reality. Ribeirão Preto: Faculdades COC, 2003. v. 1.p. 3-14.

[13] Maia, José Gilvan Rodrigues; VIDAL, C. A.; Cavalcante Neto, Joaquim Bento. Efficient Collision Detection using Transformation Semantics. In: Scott Jacobs. (Org.). Game Programming Gems 7. 1 ed. New York: Charles River Media, 2008, v. 1, p. 179-187.

[14] Maia, José Gilvan Rodrigues; VIDAL, C. A.; Cavalcante Neto, Joaquim Bento. Transformation Semantics: An Efficient Approach for Collision 
Detection. In: XIX Simpósio Brasileiro de Computação Gráfica, Processamento de Imagens e Visão Computacional, 2006, Manaus. XIX Brazilian Symposium on Computer Graphics and Image Processing. Los Alamitos: IEEE Computer Society, 2006. v. 1. p. 94-101.

[15] Mendonça Junior, Glaudiney Moreira; VIDAL, C. A.; Cavalcante Neto, Joaquim Bento. Um Modelo de Comportamento e de Interação para Entidades em Ambientes de Realidade Virtual. In: XXXII Conferencia Latinoamericana de Informática, 2006, Chile. Proceedings of the XXXII Conferencia Latinoamericana de Informática. Santiago,: 20-25 de agosto, 2006. p. 1-12.

[16] Nogueira, Yuri Lenon Barbosa; VIDAL, C. A.; Cavalcante Neto, Joaquim Bento. A Nervous System Model for Direct Dynamics Animation Control Based on Evolutionary Computation. In: 23rd Annual ACM Symposium on Applied Computing, 2008, Fortaleza. Proceedings of the 23rd Annual ACM Symposium on Applied Computing. New York: ACM, 2008. v. 3. p. 1793-1800.

[17] Nunes, Rubens Fernandes; VIDAL, C. A.; Cavalcante Neto, Joaquim Bento. Sensory state machines for physically-based animation. The Visual Computer, v. 23, p. 823-832, 2007

[18] Nunes, Rubens Fernandes; VIDAL, C. A.; Cavalcante Neto, Joaquim Bento; Zordan, Victor B. Simulando Reações Flexíveis em Movimentos Capturados. In: X Symposium on Virtual and Augmented Reality, 2008, João Pessoa. Proceedings of the 10th Symposium on Virtual and Augmented Reality. Porto Alegre: SBC, 2008. v. 1. p. 241-250.

[19] Nunes, Rubens Fernandes; VIDAL, C. A.; Cavalcante Neto, Joaquim Bento; Zordan, Victor B. Simple Feedforward Control for Responsive Motion Capture-Driven Simulations. In: 4th International Symposium on Visual Computing, 2008, Las Vegas. Lecture Notes in Computer Science - Advances in Visual Computing. Berlin Heidelberg: SpringerVerlag, 2008. v. 5358. p. 488-497.

[20] Nunes, Rubens Fernandes; VIDAL, C. A.; Cavalcante Neto, Joaquim Bento. A Flexible Representation of Controllers for Physically-based Animation of Virtual Humans. In: 22nd Annual ACM Symposium on Applied Computing, 2007, Seúl. 22nd Annual ACM Symposium on Applied Computing. Seúl: ACM, 2007. v. 1. p. 30-36.

[21] Nunes, Rubens Fernandes; VIDAL, C. A.; Cavalcante Neto, Joaquim Bento. Uma Representação Flexível de Controladores para Animação Fisicamente Realista de Personagens Virtuais. In: VIII Symposium on Virtual Reality, 2006, Belém. Proceedings of the 8th Symposium on Virtual Reality. Belém: Editora CESUPA, 2006. v. 1. p. 197-208.

[22] Santos, Emanuele Marques dos; VIDAL, C. A.; Leite Junior, Antônio José Melo; Almendra, Camilo Camilo. Beremiz - Integrando o Mathematica a um Ambiente Virtual em Rede. In: IV Symposium on Virtual Reality, 2001, Florianópolis. Proceedings of the 4th Symposium on Virtual Reality. Florianópolis: Editora da Universidade Federal de Santa Catarina, 2001. p. 238-248.

[23] Siqueira, Daniel Márcio Batista; Cavalcante Neto, Joaquim Bento; Vidal, Creto. A Hierarchical Adaptive Mesh Generation Strategy for Parametric Surfaces Based on Tree Structures. In: 23rd SIBGRAPI Conference on Graphics, Patterns and Images, 2010, Gramado. Proceedings of the 23rd Conference on Graphics, Patterns and Images. Los Alamitos: IEEE Computer Society, 2010. v. 1. p. 79-86.

[24] Siqueira, Daniel Márcio Batista; VIDAL, C. A.; Cavalcante Neto, Joaquim Bento; Silva, Romildo José. Uma Técnica de Geração de Malhas Adaptativas para Aplicações de Realidade Virtual. In: XI Symposium on Virtual and Augmented Reality, 2009, Porto Alegre. Proceedings of the 11th Symposium on Virtual and Augmented Reality. Porto Alegre: SBC, 2009. v. XI. p. 79-88.

[25] VIDAL, C. A.; Gomes, George Allan Menezes; Mendonça Junior, Glaudiney Moreira; Gomes, Humberto Ovídio Osório; Cavalcante Neto, Joaquim Bento. Uma Ferramenta de Autoria de Ambientes Virtuais Adaptável a Diferentes Motores Gráficos. In: VII Symposium on Virtual Reality, 2004, São Paulo. Proceedings of the 7th Symposium on Virtual Reality. São Paulo: Plêiade, 2004. v. 1. p. 15-26.

[26] VIDAL, C. A.; Leite Junior, Antônio José Melo; Almendra, Camilo Camilo; Santos, Emanuele Marques dos; Oliveira, Joaquim Pedro C.; Costa Filho, João Carlos da Silveira. A Virtual Environment for
Distance Learning. In: Deryn Watson; Jane Andersen. (Org.) NETWORKING THE LEARNER - Computers in Education. 1 ed. Norwell, Massachusetts, USA: Kluwer Academic Publishers, 2002, v. 1 , p. 95-103.

[27] VIDAL, C. A.; Santos, Emanuele Marques dos; Gomes, Humberto Ovídio Osório; Leite Junior, Antônio José Melo. Virtual Reality in Language Learning: The VRTourist Project. In: XII International Conference on Computers in Education, 2004, Melbourne. Proceedings of the 9th International Conference on Computers in Education. Melbourne: RMTI, 2004. v. 1. p. 265-272.

[28] VIDAL, C. A.; Santos, Emanuele Marques dos; Leite Junior, Antônio José Melo; Almendra, Camilo Camilo; Borges, Vládia Maria Cabral. Collaborative Virtual Environments for Language Learning. In: VI Symposium on Virtual Reality, 2003, Ribeirão Preto. Proceedings of the 6th Symposium on Virtual Reality. Ribeirão Preto: Faculdades COC, 2003. v. 1. p. 309-320.

[29] VIDAL, C. A.; Santos, Emanuele Marques dos; Leite Junior, Antônio José Melo; Almendra, Camilo Camilo; Borges, Vládia Maria Cabral. A Tour Guide Course using Collaborative Virtual Environments. In: XIV Simpósio Brasileiro de Informática na Educação, 2003, Rio de Janeiro. Anais do XIV Simpósio Brasileiro de Informática na Educação. Rio de Janeiro, 2003. v. 1. p. 657-666.

[30] Vieira, Roberto César Cavalcante; VIDAL, C. A.; Cavalcante Neto, Joaquim Bento. A Biologically Inspired Generation of Virtual Characters. In: 23rd Annual ACM Symposium on Applied Computing, 2008, Fortaleza. Proceedings of the 23rd Annual ACM Symposium on Applied Computing. New York: ACM, 2008. v. 2. p. 1218-1224.

[31] Vieira, Roberto César Cavalcante; VIDAL, C. A.; Cavalcante Neto, Joaquim Bento. Transmissão de Características Genéticas na Geração de Personagens Virtuais. In: X Symposium on Virtual and Augmented Reality, 2008, João Pessoa. Proceedings of the 10th Symposium on Virtual and Augmented Reality. Porto Alegre: SBC, 2008. v. 1. p. 348358.

[32] Vieira, Roberto César Cavalcante; VIDAL, C. A.; Cavalcante Neto, Joaquim Bento. Geração de Personagens Virtuais Simulando o Processo Reprodutivo de Seres Diplóides. In: IX Symposium on Virtual and Augmented Reality - SVR2007, 2007, Petrópolis. Porceedings of the 9th Symposium on Virtual and Augmented Reality. Porto Alegre: SBC, 2007. v. IX. p. 170-179.

[33] Vieira, Roberto César Cavalcante; Vidal, Creto; Cavalcante Neto, Joaquim Bento. Expression Cloning Based on Anthropometric Proportions and Deformations by Motion of Spherical Influence Zones. SBC Journal on 3D Interactive Systems, v. 2, p. 14-22, 2011.

[34] Vieira, Roberto César Cavalcante; Vidal, Creto; Cavalcante Neto, Joaquim Bento. Simulation of Genetic Inheritance in the Generation of Virtual Characters. In: IEEE Virtual Reality, 2010, Waltham, Massachusetts. IEEE Virtual Reality Conference 2010 (VR 2010), 20-24 March 2010, Waltham, Massachusetts, USA, Proceedings 2010. Piscataway, NJ: IEEE Computer Society, 2010. v. 1. p. 119-126.

[35] Vieira, Roberto César Cavalcante; Vidal, Creto; Cavalcante Neto, Joaquim Bento. Mapeamento Automático de Expressões Faciais Baseado em Proporções de Medidas Antropométricas. In: Symposium on Virtual and Augmented Reality, 2010, Natal. Proceedings of the 12th Symposium on Virtual and Augmented Reality. Porto Alegre: SBC, 2010. v. 1. p. 84-92.

[36] Vieira, Roberto César Cavalcante; Vidal, Creto; Cavalcante Neto, Joaquim Bento. Caricaturização de Personagens Virtuais por Deformação de Medidas Antropométricas. In: Symposium on Virtual and Augmented Reality, 2010, Natal. Proceedings of the 12th Symposium on Virtual and Augmented Reality. Porto Alegre: SBC, 2010. v. 1. p. 93-101.

[37] Vieira, Roberto César Cavalcante; Vidal, Creto; Cavalcante Neto, Joaquim Bento. Manipulação Corporal de Personagens Virtuais por Deformações de Medidas Antropométricas. In: Symposium on Virtual and Augmented Reality, 2010, Natal. Proceedings of the 12th Symposium on Virtual and Augmented Reality. Porto Alegre: SBC, 2010. v. 1. p. 102-111. 